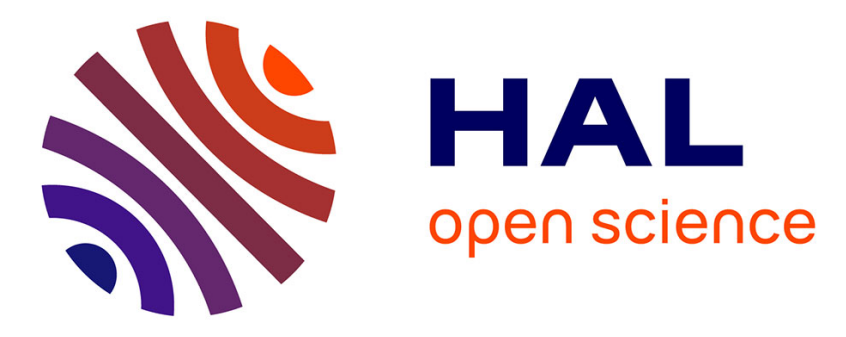

\title{
Environmental factors influencing landfill gas biofiltration: Lab scale study on methanotrophic bacteria growth
}

Corrado Amodeo, Adriano Sofo, Maria Teresa Tito, Antonio Scopa, Salvatore Masi, Raffaella Pascale, Ignazio Mancini, Donatella Caniani

\section{To cite this version:}

Corrado Amodeo, Adriano Sofo, Maria Teresa Tito, Antonio Scopa, Salvatore Masi, et al.. Environmental factors influencing landfill gas biofiltration: Lab scale study on methanotrophic bacteria growth. Journal of Environmental Science and Health, Part A, 2018, 53 (9), pp.825-831. 10.1080/10934529.2018.1455342 . hal-02010879

\section{HAL Id: hal-02010879 https://hal.science/hal-02010879}

Submitted on 7 Feb 2019

HAL is a multi-disciplinary open access archive for the deposit and dissemination of scientific research documents, whether they are published or not. The documents may come from teaching and research institutions in France or abroad, or from public or private research centers.
L'archive ouverte pluridisciplinaire HAL, est destinée au dépôt et à la diffusion de documents scientifiques de niveau recherche, publiés ou non, émanant des établissements d'enseignement et de recherche français ou étrangers, des laboratoires publics ou privés. 


\section{Environmental factors influencing landfill gas biofiltration: Lab scale study on methanotrophic bacteria growth}

\section{Corrado Amodeo, Adriano Sofo, Maria Teresa Tito, Antonio Scopa, Salvatore} Masi, Raffaella Pascale, Ignazio M. Mancini \& Donatella Caniani

To cite this article: Corrado Amodeo, Adriano Sofo, Maria Teresa Tito, Antonio Scopa, Salvatore Masi, Raffaella Pascale, Ignazio M. Mancini \& Donatella Caniani (2018): Environmental factors influencing landfill gas biofiltration: Lab scale study on methanotrophic bacteria growth, Journal of Environmental Science and Health, Part A, DOI: 10.1080/10934529.2018.1455342

To link to this article: https://doi.org/10.1080/10934529.2018.1455342

曲 Published online: 29 Mar 2018.

Submit your article to this journal $₫$

Џ Article views: 2

View related articles

View Crossmark data $\asymp$ 


\title{
Environmental factors influencing landfill gas biofiltration: Lab scale study on methanotrophic bacteria growth
}

\author{
Corrado Amodeo ${ }^{a}$, Adriano Sofo $^{b}$, Maria Teresa Tito $^{a}$, Antonio Scopa $^{b}$, Salvatore Masi ${ }^{a}$, Raffaella Pascale $^{a}$, \\ Ignazio M. Mancini ${ }^{a}$, and Donatella Caniani ${ }^{\mathrm{a}}$
}

${ }^{a}$ School of Engineering, University of Basilicata, Lucano, Potenza, Italy; ${ }^{\mathrm{b}}$ School of Agricultural, Forestry, Food and Environmental Sciences, University of Basilicata, Lucano, Potenza, Italy

\begin{abstract}
The post-management of landfills represents an important challenge for landfill gas treatment. Traditional systems (energy recovery, flares, etc.) present technical problems in treating flow with low methane $\left(\mathrm{CH}_{4}\right)$ concentrations. The objective of this study was to isolate methanotrophic bacteria from a field-scale biofilter in order to study the bacteria in laboratories and evaluate the environmental factors that mostly influence Microbial Aerobic Methane Oxidation (MAMO). The soil considered was sampled from the biofilter located in the landfill of Venosa (Basilicata Region, Italy) and it was mainly composed of wood chips and compost. The results showed that methanotrophic microorganisms are mainly characterized by a slow growth and a significant sensitivity to $\mathrm{CH}_{4}$ levels. Temperature and nitrogen $(\mathrm{N})$ also have a very important role on their development. On the basis of the results, biofilters for biological $\mathrm{CH}_{4}$ oxidation can be considered a viable alternative to mitigate $\mathrm{CH}_{4}$ emissions from landfills.
\end{abstract}

\section{ARTICLE HISTORY}

Received 7 December 2017

Accepted 20 February 2018

\section{KEYWORDS}

Biofiltration; Biolog ${ }^{\circledR}$; methane oxidation; methanotrophic bacteria; landfill methane emissions

\section{Introduction}

The anaerobic decomposition of urban solid waste in landfills causes the production of landfill gas (LFG). LFG composition is a mixture of different gases that changes according to different conditions. Methane $\left(\mathrm{CH}_{4}\right)$ and carbon dioxide $\left(\mathrm{CO}_{2}\right)$ are the prevalent gases in the LFG flow, but nitrogen $\left(\mathrm{N}_{2}\right)$ and other trace gases, such as volatile organic hydrocarbons (VOCs), may be present in the flow. ${ }^{[1]}$

Both, $\mathrm{CH}_{4}$ and $\mathrm{CO}_{2}$ are considered strong greenhouse gases (GHGs) due to their capacity in absorbing and emitting infrared radiation. However, $\mathrm{CH}_{4}$ has a global warming potential (GWP) 25 times stronger than $\mathrm{CO}_{2} \cdot{ }^{[2]}$ Tropospheric concentrations of methane increased from 722 part per billion (ppb) in the preindustrial age to $1834 \mathrm{ppb}$ in $2016 .{ }^{[3]} \mathrm{CH}_{4}$ emitted from landfills has historically been considered the largest source of GHG emissions from the waste sector ${ }^{[2]}$ : the global $\mathrm{CH}_{4}$ emissions from landfills are estimated to be $500-800 \mathrm{Mt} \mathrm{CO}_{2}$-eq year- ${ }^{1}{ }^{[4-6]}$

The implementation of vertical wells or horizontal collectors for active LFG extraction linked to energy-recovery plants is common in landfills in developed countries and represents the most important mitigation measure to reduce GHG emissions. ${ }^{[2]}$ Nevertheless, energy recovery plants need to have a high LFG flow and $\mathrm{CH}_{4}$ concentration to produce energy. In these situations, LFG combustion by flares represents the most common technical solution. ${ }^{[7]}$ However, increasing the landfill post management period, LFG flow and $\mathrm{CH}_{4}$ concentration decrease, and flares are not always capable to oxidize $\mathrm{CH}_{4}$ by combustion; normally, the minimum flow must be $50 \mathrm{Nm}^{3} \mathrm{~h}^{-1}$ and the minimum $\mathrm{CH}_{4}$ concentration $30 \%\left(\mathrm{v} \mathrm{v}^{-1}\right){ }^{[8]}$ The same technical problems can be observed in small landfills, where LFG flow and $\mathrm{CH}_{4}$ concentration are not enough for traditional LFG treatment systems. ${ }^{[9]}$

In the abovementioned circumstances, Microbial Aerobic Methane Oxidation (MAMO) represents a viable alternative to traditional systems for LFG treatment. ${ }^{[10]}$ The MAMO process is due to methanotrophic bacteria (also called "methanotrophs"), a subset of a physiological group of bacteria known as methylotrophs. ${ }^{[1]}$ Methanotrophs have the capacity of oxidizing $\mathrm{CH}_{4}$ in aerobic conditions. ${ }^{[12]}$ Methanotrophs have $\mathrm{CH}_{4}$ as a carbon and energy source, and use the enzyme methane-monooxygenases (MMOs) to catalyse the oxidation of $\mathrm{CH}_{4}$ to methanol $\left(\mathrm{CH}_{3} \mathrm{OH}\right)$, followed by oxidation of methanol to formaldehyde $(\mathrm{CHOH})$ and the subsequent oxidation of formaldehyde to formate $(\mathrm{CHOOH})$, before the final conversion to $\mathrm{CO}_{2}{ }^{[13]}$

The biochemical reaction $\left(\Delta^{\circ} \mathrm{G}=-780 \mathrm{~kJ} \mathrm{~mol}^{-1} \mathrm{CH}_{4}\right.$, $\left.\Delta^{\circ} \mathrm{H}=-890 \mathrm{~kJ} \mathrm{~mol}^{-1}\right)$ is the following ${ }^{[14,15]}$ :

$$
\mathrm{CH}_{4}+(2-x) \mathrm{O}_{2} \rightarrow(1-x) \mathrm{CO}_{2}+(2-x) \mathrm{H}_{2} \mathrm{O}+\text { heat }
$$

The kinetics of this process was described by Scheutz et al., ${ }^{[13]}$ Abichou et al. ${ }^{[16]}$ and $\mathrm{Ng}$ et al. ${ }^{[15]}$ as:

$$
r=\frac{V_{\max } \cdot C_{C_{4}}}{K_{m}^{C H_{4}}+C_{C_{4}}} \cdot \frac{C_{o_{2}}}{K_{m}^{O_{2}}+C_{o_{2}}}
$$

where $r=\mathrm{CH}_{4}$ oxidation rate $\left[\mathrm{mol}\left(\mathrm{m}^{3} \mathrm{~h}\right)^{-1}\right], V_{\max }=$ maximum $\mathrm{CH}_{4}$ oxidation rate $\left[\mathrm{mol}\left(\mathrm{m}^{3} \mathrm{~h}\right)^{-1}\right], K_{m}=$ Michaelis- 
Menten or half-saturation constant $\left[\mathrm{mol} \mathrm{m}^{-3}\right]$, and $C=$ concentration $\left[\mathrm{mol} \mathrm{m}^{-3}\right]$.

The biofiltration is a biological process in which MAMO occurs. The biofilter is an aerobic reactor, generally a container with standard sizes (easier to set up), filled with packing material. The packing material is very important as it is the core of the process. Many researchers focused their studies on the choice of the best packing material to improve MAMO efficiency. ${ }^{[17-20]}$ Wood chips have been detected as an excellent packing material due to their capacity to support and sustain the development of a methanotrophic biofilm. ${ }^{[21]}$ In landfills, the collectors of active LFG extraction lead the gas to the base of the biofilter through a piping system. In this way, LFG is conducted to the packing material by natural trend. An empty space is placed at the bottom of the system to avoid preferential pathways and to allow an LFG homogeneous diffusion over the entire oxidation surface. ${ }^{[8]}$

Several environmental parameters influence the MAMO efficiency, as with all biological processes. Among them, the most influential, as it is expected for biological processes, is the temperature. Generally, methanotrophs are mesophile bacteria and the perfect range for their development is between 25 and $35^{\circ} \mathrm{C}^{[22-24]}$ The moisture of the packing material also represents an important parameter to facilitate the nutrient supply and the optimal range is $10-20 \%\left(\mathrm{w} \mathrm{w}^{-1}\right)^{[25]}: 5 \%$ is the threshold below which the bacteria activity dramatically drops. ${ }^{[26-28]}$ The optimal $\mathrm{pH}$ lies between 5.5 and 8.5. ${ }^{[13]}$

The aim of this study was to isolate methanotrophic bacteria from a field-scale biofilter in order to evaluate the environmental factors that most influence MAMO. The soil was sampled from the biofilter located in the landfill of Venosa (Basilicata Region, Italy) and it was mainly composed of wood chips and compost.

\section{Materials and methods}

\section{Full-scale biofilter}

In 2014, a biofilter for the LFG treatment was installed in the Venosa landfill. It was designed and built by a collaboration between the Sanitary Engineering research group of the Basilicata University and the private company Entsorga Italia Spa (Tortona, AL, Italy). The biofilter was implemented in a $20 \mathrm{ft}$ (feet) standard container (external measurements: length $6.058 \mathrm{~m}$, width $2.438 \mathrm{~m}$, height $2.591 \mathrm{~m}$ ). The packing material was leaned on an internal base, leaving $55 \mathrm{~cm}$ of empty space at the bottom of the container. In this way, the LFG could be uniformly distributed over the entire oxidation surface avoiding preferential pathways. According to most scientific studies, ${ }^{[13,21},{ }^{29]}$ a mix of wood chips and compost was selected as the packing material (the main characteristics are reported in Table 1).

Approximately $19 \mathrm{~m}^{3}$ of packing material were introduced in the container $(1.4 \mathrm{~m}$ height). About $20 \mathrm{~cm}$ of empty space was left on top, between the packing material and a geomembrane located under the closing system. The geomembrane has the task of retaining the moisture in the system, letting the treated LFG pass. Furthermore, a wet system linked to a water tank was set up on the final closure to ensure constant
Table 1. Packing material characteristics.

\begin{tabular}{lcc}
\hline Parameter & Value & U.M. \\
\hline $\mathrm{pH}$ & 8.04 & - \\
Moisture & 48.66 & $\%$ t.q. \\
Dry matter & 51.34 & $\%$ t.q. \\
Organic matter & 78.10 & $\%$ s.s. \\
$\mathrm{N}$ tot & 1.35 & $\%$ s.s. \\
$\mathrm{CIM}$ & 190 & $\% \mathrm{~s} . \mathrm{s}$ \\
Bulk density & 0.38 & $\mathrm{~g} \mathrm{~cm}^{-3}$ \\
Density & 1.55 & $\mathrm{~g} \mathrm{~cm}^{-3}$ \\
Total Porosity & 75.48 & $\%$ \\
Dynamic Respiration Index & 615 & $\mathrm{mg}_{\mathrm{oz}} \mathrm{kg}_{\mathrm{ss}}^{-1} \mathrm{~h}^{-1}$ \\
\hline
\end{tabular}

moisture. All the treated LFG comes out of a chimney located at the top of the container. A discharge valve was also installed at the bottom to unload the leachate. A blower $(7.5 \mathrm{~kW}$, $2900 \mathrm{rpm}$ ) was implemented and linked to the landfill pipelines (already connected to the landfill vertical wells) to bring LFG to the biofilter. Figure 1 shows the biofilter design.

The biofilter was was put in operation in 2015. The test site and the measurements of $\mathrm{CH}_{4}$ oxidation efficiency of the biofilter are shown in Figure 2 and Table 2, respectively.

\section{Methanotrophs growth}

Three replicates of $10 \mathrm{~g}$-subsamples (dry weight equivalent) of the biofilter packing material (sampled from the top of the packing material) were suspended in $90 \mathrm{~mL}$ sterile $0.18 \%$ sodium pyrophosphate-one quarter strength Ringer solution $(\mathrm{NaCl}$ $2.25 \mathrm{~g} \mathrm{~L}^{-1}, \mathrm{KCl} 0.105 \mathrm{~g} \mathrm{~L}^{-1}, \mathrm{CaCl}_{2} 0.045 \mathrm{~g} \mathrm{~L}^{-1}, \mathrm{NaHCO}_{3} 0.05 \mathrm{~g}$ $\mathrm{L}^{-1}$, and citric acid $0.034 \mathrm{~g} \mathrm{~L}^{-1}$ ), sonicated for 2 min to disperse particles, and left at $4^{\circ} \mathrm{C}$ for $15 \mathrm{~min}$ to disperse microbial cells. Ten-fold serial dilutions of the supernatants were made in sterile one-quarter strength Ringer solution. Aliquots $(100 \mu \mathrm{L})$ of the $10^{-1}, 10^{-3}$, and $10^{-5}$ dilutions were spread plated in duplicate in Petri dishes on a medium (M1) for the growth of methanotrophs having the following characteristics ${ }^{[30]}: \mathrm{K}_{2} \mathrm{HPO}_{4} 0.5 \mathrm{~g} \mathrm{~L}^{-1}$, $\mathrm{MgSO}_{4} \cdot 7 \mathrm{H}_{2} \mathrm{O} 0.2 \mathrm{~g} \mathrm{~L}^{-1}, \mathrm{CaCl}_{2} 0.015 \mathrm{~g} \mathrm{~L}^{-1}, 0.001 \mathrm{~g} \mathrm{~L}^{-1} \mathrm{FeSO}_{4}$. $2 \mathrm{H}_{2} \mathrm{O}, 0.001 \mathrm{~g} \mathrm{~L}^{-1} \mathrm{Na}_{2} \mathrm{MoO}_{4} \cdot 2 \mathrm{H}_{2} \mathrm{O}$, bacteriological agar 12.5 $\mathrm{g} \mathrm{L}^{-1}, \mathrm{pH}$ 6.8. A second medium (M2) was prepared using the same concentrations as described above and adding $1.43 \mathrm{~mL}$ of $\mathrm{NH}_{3}$ solution $\left(70 \% \mathrm{w} \mathrm{w}^{-1}\right)$, for a final concentration of $20 \mathrm{mM}$ $\mathrm{NH}_{3}$. The final $\mathrm{pH}$ of medium $\mathrm{M} 2$ was 9.8 and it was corrected to 6.8 by adding drops of ultrapure $\mathrm{HNO}_{3}$ for a final solution volume of $1 \mathrm{~L}$. All the chemicals used were purchased from Sigma-Aldrich (Trace-SELECT ${ }^{\circledR}$; St. Louis, MO, USA). A total of 144 Petri dishes were prepared: 72 containing M1 and 72 containing M2. The dishes were placed in special polyethylene sterile bags with a hermetic seal (Sigma Aldrich AtmosBag two-hand, size S, Z118370). Each bag (4 in total) contained 36 dishes: 18 filled with medium M1 (three sample replicates with three dilutions in duplicate) and 18 filled with medium M2 (three sample replicates with three dilutions in duplicate). Two bags were incubated at $20^{\circ} \mathrm{C}$ and the remaining two at $35^{\circ} \mathrm{C}$. For every incubation temperature, the two bags were filled with different proportions of air and biogas, as described in the following paragraph. The biogas used was taken from the biogas recovery system installed in the landfill described above. Bacterial counting took place throughout a period of 100 days from plating (5 May 2016). 


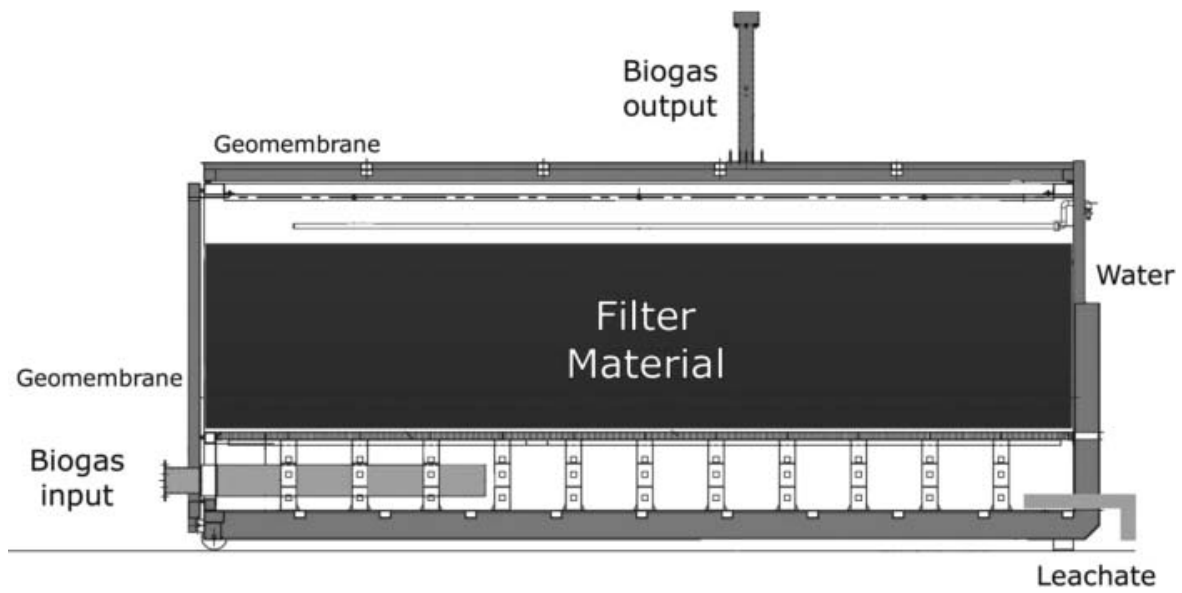

Figure 1. Cross-sectional details of the biofilter.

\section{Biogas analysis}

Before filling the bags with air/biogas, biogas composition was analyzed in several dates. $\mathrm{CH}_{4}$ and $\mathrm{CO}_{2}$ gas concentrations were determined in a Shimadzu 2010 gas chromatograph-barrier ionization discharge detector (GC-BID) (Shimadzu, Kyoto, Japan) equipped with a Restek ShinCarbon ST micropacked column $(2 \mathrm{~m} \times 1 \mathrm{~mm}$ i.d.) (Restek Corporation, Bellefonte, USA). Such GC-BID system was previously described by Pascale et al. ${ }^{[31]}$ Briefly, the oven temperature was set to $30^{\circ} \mathrm{C}$ for $5 \mathrm{~min}$ and was increased to $120^{\circ} \mathrm{C}$ at a rate of $10^{\circ} \mathrm{C} / \mathrm{min}$. The injector and detector temperatures were maintained at $150^{\circ} \mathrm{C}$ and $250^{\circ} \mathrm{C}$, respectively. Helium with a 6.0 purity (SIAD Corporation, Bergamo, Italy) was used as the carrier gas at $15 \mathrm{~mL} / \mathrm{min}$ during chromatographic separation and as the BID discharge gas at $80 \mathrm{~mL} / \mathrm{min}$. All injections were made in the direct mode by using a gastight syringe (injection volume $250 \mathrm{ul}$ ). For GC-BID quantitative analyses, three calibration gas standards of $\mathrm{CO}_{2}$ and $\mathrm{CH}_{4}$ were prepared over the range of desired concentrations $\left(50-1000 \mathrm{ppm}_{\mathrm{v}}\right)$ by diluting the pure $\mathrm{CH}_{4}(99.995 \%)$ and $\mathrm{CO}_{2} \quad(99.995 \%)$ (Sigma Aldrich, Milano, Italy) with ambient air. $10 \mathrm{~mL}, 1 \mathrm{~mL}$, $250 \mu \mathrm{L}$ and $100 \mu \mathrm{L}$ gas-tight syringes (Sigma Aldrich a)

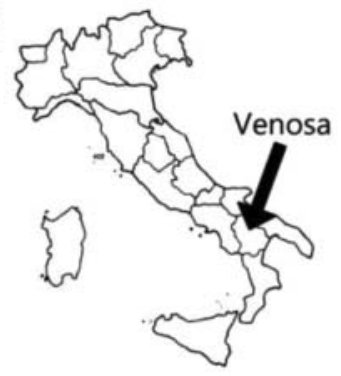

b)

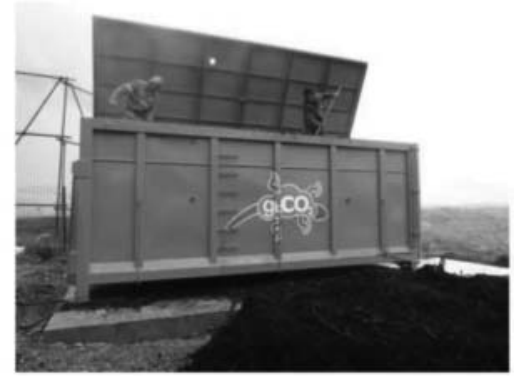

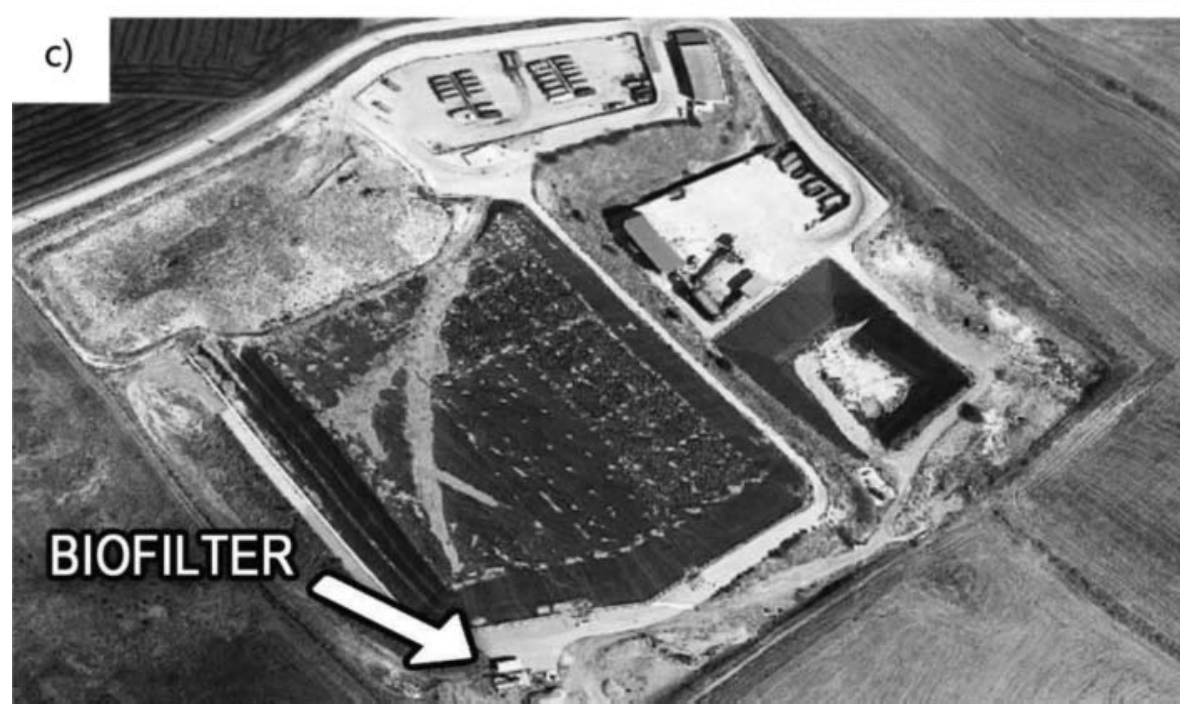

Figure 2. The test site. (a) Location of Venosa; (b) Picture of Biofilter; (c) Satellite Image of the Venosa landfill. 
Table 2. Methane oxidation efficiency considering the percentage of methane in the biogas flow in input $\mathrm{CH}_{4} \mathrm{IN}$ and output of the Venosa biofilter.

\begin{tabular}{lcccc}
\hline Date & Biogas Flow $\left(\mathrm{Nm}^{3} \mathrm{~h}^{-1}\right)$ & $\mathrm{CH}_{4 \text { IN }}$ (\% vol.) & $\mathrm{CH}_{4 \text { out }}$ (\% vol.) & CH4 oxidation efficiency (\%) \\
\hline $08 / 02 / 2016$ & 24.0 & 1.15 & 0.65 & 43.48 \\
$13 / 05 / 2016$ & 12.6 & 3.4 & 1.9 & 44.12 \\
$27 / 05 / 2016$ & 10.2 & 8.3 & 4.04 & 51.32 \\
\hline
\end{tabular}

Milano, Italy) were used for preparing calibration standards at different concentrations $\left(50,500,1000 \mathrm{ppm}_{\mathrm{v}}\right)$ in 1 and 10 L Tedlar sampling bags equipped with PTFE fittings (Zefon International, Ocala, USA) via a Gilian GilAirSampling Pump (Sensidyne, St. Petersburg, USA). The results revealed the following average composition: 54\% [ $\left[\mathrm{v} \mathrm{v}^{-1}\right]$ $\mathrm{CH}_{4}, 31 \% \mathrm{CO}_{2}, 13 \% \mathrm{~N}_{2}, 1.6 \% \mathrm{O}_{2}$. Two bags were filled with $30 \mathrm{~L}$ of atmospheric air: biogas in the proportion of 1:1 $\left(\mathrm{v} \mathrm{v}^{-1}\right)$ by means of an electronic pump (Gilian GilAir Sampling Pump - Sensidyne, St. Petersburg, USA) with a volumetric counter, resulting in an approximated final composition of $27 \%\left(\mathrm{v} \mathrm{v}^{-1}\right) \mathrm{CH}_{4}, 15 \% \mathrm{CO}_{2}, 46 \% \mathrm{~N}_{2}, 11 \% \mathrm{O}_{2}$ $\left(\mathrm{CH}_{4}: \mathrm{O}_{2}\right.$ ratio $\left.=1: 0.4\right)$. The other two bags were filled with $30 \mathrm{~L}$ of atmospheric air: biogas in the proportion of 72:28 $\left(\mathrm{v} \mathrm{v}^{-1}\right)$, resulting in an approximated final composition of $15 \%\left(\mathrm{v} \mathrm{v}^{-1}\right) \mathrm{CH}_{4}, 9 \% \mathrm{CO}_{2}, 60 \% \mathrm{~N}_{2}, 15 \% \mathrm{O}_{2}\left(\mathrm{CH}_{4}: \mathrm{O}_{2}\right.$ ratio $=1: 1)$.

\section{Soil physicochemical parameters and Biolog ${ }^{\circledR}$ analysis}

The measurements of $\mathrm{pH}$, electric conductivity, total organic matter, total nitrogen $(\mathrm{N})$, potassium $(\mathrm{K})$ and phosphorus (Olsen) (P) of the biofilter packing material were determined in triplicate according to the official methods of the Italian Society of Soil Science (SISS, 2000).

Carbon source utilization pattern of the bacterial communities, also called community-level physiological profiles (CLPPs), of landfill soil was assessed in triplicate using the Biolog $^{\circledR}$ 96-well Eco-MicroDishes ${ }^{\mathrm{TM}}$ (AES Laboratoire, France), containing 31 different carbon sources, following the manufacturer's instructions. For each well of the Biol$\operatorname{og}^{\circledR}$ MicroDishes ${ }^{\mathrm{TM}}$, an aliquot of $100 \mu \mathrm{L}$ of the same landfill soil at $10^{-3}$ dilution used for the bacterial count was used for the Biolog ${ }^{\circledR}$ assay. The microdishes were incubated at $25^{\circ} \mathrm{C}$ in the dark. Color development, due to the utilization of carbon sources by bacteria, was measured every $24 \mathrm{~h}$ over a $144 \mathrm{~h}$-period using a Microplate E-Max Reader (Bio-Rad; Hercules, CA USA) with an E590-nm wavelength filter.

Data were analyzed to determine metabolic diversity indices, according to Zak et al. ${ }^{[32]}$ and $\mathrm{Xu}$ et al. ${ }^{[33]}$ Average well color development $(A W C D)$, that provides a measure of the total cultural bacterial activity, was calculated as follows:

$$
A W C D=\sum \frac{\left(c_{i}-R\right)}{W}
$$

where $c_{i}$ is the $\mathrm{OD}_{590 \mathrm{~nm}}$ in each well; $R$ is the $\mathrm{OD}_{590 \mathrm{~nm}}$ in the control well; and $W$ is the number of all the wells. The carbon substrates of the Biolog ${ }^{\circledR}$ dishes were divided into eight main groups of compounds, respectively, and the AWCD value for each group was calculated.

\section{Statistical analysis}

Statistical analysis of data was carried out using STATISTICA v6.0 (StatSoft Inc.; Vigonza, PD, Italy). The values of bacterial microbial counts and Biolog ${ }^{\circledR} A W C D$ (three independent replicates for each treatment; $n=9$ ) were examined by using a variance analysis (ANOVA). Means were separated according to Duncan's multiple comparison test at $P \leq 0.05$.

\section{Results and discussion}

\section{Methanotrophic microorganisms}

The biological analysis of the biofilter packing material was aimed to test different combinations of $\mathrm{N}$ content, $\mathrm{CH}_{4}$ levels (and consequent $\mathrm{CH}_{4}: \mathrm{O}_{2}$ ratios) and temperature for the growth of methanotrophs in the examined substrate. The choice of the highly selective cultural medium ${ }^{[30]}$ was successful, as it allowed the isolation of methanotrophs due to the lack of carbon sources other than $\mathrm{CH}_{4}$ and $\mathrm{CO}_{2}$ in the air mixture which was blown in. The presence of $\mathrm{O}_{2}$ was necessary because methanotrophs are aerobic bacteria. Whereas, for the required $\mathrm{N}$, methanotrophs can use both inorganic $\mathrm{N}$ sources or can fix atmospheric $\mathrm{N}_{2}$. The choice of adding $\mathrm{NH}_{3}$ (and $\mathrm{HNO}_{3}$ for the $\mathrm{pH}$ correction) was done in order to avoid the addition of other nutrients in the culture medium, which could have influenced the microbial growth in an unpredictable way.

The microbial counts obtained from our experiments are reported in Table 3.

According to what was reported in literature, ${ }^{[11,34,35]}$ methanotrophic microorganisms are mainly characterized by a slow growth. Numerous manuals of microbiology indicate that it is necessary to wait for at least 2-3 weeks for the appearance of the first colonies of significant size. Indeed, after five days of incubation, no colonies were identified in the dishes, while, after 10 days of incubation, the first colonies appeared at the lowest dilution $\left(10^{-1}\right)$ only in the dishes without $\mathrm{N}$.

After 13 days of incubation at $20^{\circ} \mathrm{C}$, colonies appeared also at the highest dilution $\left(10^{-3}\right.$ and $\left.10^{-5}\right)$. Interestingly, the microbial growth was higher in the dishes without $\mathrm{N}$ and in the bags with 1:0.4 $\mathrm{CH}_{4}: \mathrm{O}_{2}$ ratio. Therefore, it seems that the addition of $\mathrm{N}$ strongly inhibited microbial growth. In the bags with 1:1 $\mathrm{CH}_{4}: \mathrm{O}_{2}$ ratio, the inhibition due to $\mathrm{N}$ also occurred, but colonies were significantly lower than in the bags with a high $\mathrm{CH}_{4}$ level (3000 vs 3500 UFC). This demonstrates the positive correlation between $\mathrm{CH}_{4}$ concentration and microbial growth. The same microbial counts were carried out after 13 days in the dishes incubated at $35^{\circ} \mathrm{C}$, where the growth of methanotrophs was lower, compared to the $20^{\circ} \mathrm{C}$ incubation. This is in agreement with researchers that report methanotrophs as mesophilic bacteria, with an optimum growth rate between 20 and $25^{\circ} \mathrm{C}^{[13,36,37]}$ 


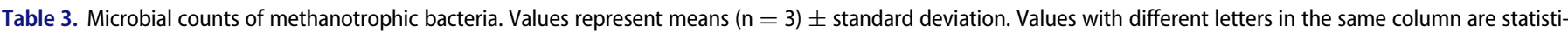
cally different at $\mathrm{P} \leq 0.05$, according to Duncan's multiple comparison test.

\begin{tabular}{|c|c|c|c|c|c|c|c|}
\hline \multirow[b]{2}{*}{ Medium } & \multirow[b]{2}{*}{ Temp. $\left({ }^{\circ} \mathrm{C}\right)$} & \multirow[b]{2}{*}{$\mathrm{CH}_{4}: \mathrm{O}_{2}$ ratio } & \multicolumn{5}{|c|}{$\begin{array}{l}\text { Days of incubation } \\
\text { Microbial counts (CFU/g soil FW) }\end{array}$} \\
\hline & & & 5 & 10 & 13 & 21 & 30 \\
\hline \multirow[t]{4}{*}{ M1 (- N) } & 20 & 1.1 & $0 \pm 0 \mathrm{a}$ & $120 \pm 25 b$ & $3000 \pm 80 b$ & $2100 \pm 160 b$ & $2300 \pm 350 b$ \\
\hline & & $1: 0.4$ & $0 \pm 0 \mathrm{a}$ & $250 \pm 25 a$ & $3500 \pm 95 a$ & $2700 \pm 250 a$ & $3000 \pm 220 a$ \\
\hline & 35 & 1.1 & $0 \pm 0 \mathrm{a}$ & $10 \pm 5 d$ & $1000 \pm 120 d$ & $800 \pm 180 d$ & $1000 \pm 150 c$ \\
\hline & & $1: 0.4$ & $0 \pm 0 \mathrm{a}$ & $30 \pm 10 c$ & $1600 \pm 235 c$ & $1200 \pm 350 c$ & $1200 \pm 190 c$ \\
\hline \multirow[t]{4}{*}{$\mathrm{M} 2(+\mathrm{N})$} & 20 & 1.1 & $0 \pm 0 \mathrm{a}$ & $0 \pm 0 \mathrm{e}$ & $140 \pm 20 f$ & $150 \pm 25 \mathrm{f}$ & $300 \pm 50$ e \\
\hline & & $1: 0.4$ & $0 \pm 0 \mathrm{a}$ & $0 \pm 0 \mathrm{e}$ & $300 \pm 30 \mathrm{e}$ & $400 \pm 30 \mathrm{e}$ & $600 \pm 50 d$ \\
\hline & 35 & 1.1 & $0 \pm 0 \mathrm{a}$ & $0 \pm 0 \mathrm{e}$ & $0 \pm 0 \mathrm{~g}$ & $0 \pm 0 \mathrm{~g}$ & $0 \pm 0 \mathrm{f}$ \\
\hline & & $1: 0.4$ & $0 \pm 0 \mathrm{a}$ & $0 \pm 0 \mathrm{e}$ & $0 \pm 0 \mathrm{~g}$ & $0 \pm 0 \mathrm{~g}$ & $0 \pm 0 \mathrm{f}$ \\
\hline
\end{tabular}

After 21 days of incubation, microbial growth slowed down (2700 UFC compared to 3500 UFC taken from the previous reading at $20^{\circ} \mathrm{C}$ incubation in the bags with high $\mathrm{CH}_{4}$ levels). This was likely due to a growth block due to the consumption of the $\mathrm{CH}_{4}$ in the bags, considering that $\mathrm{CH}_{4}$ was the only carbon source available in the medium. Indeed, in the bags with low $\mathrm{CH}_{4}$, the growth was completely inhibited, demonstrating the sensitivity of the microorganisms to $\mathrm{CH}_{4}$ levels. In order to avoid this problem, bags were deflated with the electronic pump and the air replaced with a new insufflation at the same $\mathrm{CH}_{4}: \mathrm{O}_{2}$ ratio previously used.

Finally, after one month of incubation (8 June 2016), all four bags were opened and the final microbial counts were carried out. Again, the microbial growth was significantly higher in the dishes without $\mathrm{N}$ addition and in those incubated in the atmosphere containing more $\mathrm{CH}_{4}$. As reported in Figure 3, the comparison of the two incubation temperatures shows that the number and the diameter of the colonies incubated at $20^{\circ} \mathrm{C}$ was significantly higher than that of the colonies at $35^{\circ} \mathrm{C}$. The inhibitory effect of $\mathrm{N}$ addition was significant also in the dishes incubated at $35^{\circ} \mathrm{C}$ where microbial growth was lower. This could explain the controversy about the growth of $\mathrm{N}$ and methanotrophs observed by some authors, ${ }^{[11,34,36]}$ which also seems to be temperature-dependent.

The results demonstrated that, at the concentration used in this study $\left(20 \mathrm{mM} \mathrm{NH} \mathrm{NH}_{3}\right), \mathrm{N}$ is still not enough to completely inhibit microbial growth. This suggests that an eventual addition of nutrients to the biofilter should be carried out adding a fertilizer containing $\mathrm{P}, \mathrm{K}$ and $\mathrm{N}$, but maintaining $\mathrm{N}$ under a certain threshold in order not to inhibit bacterial growth.
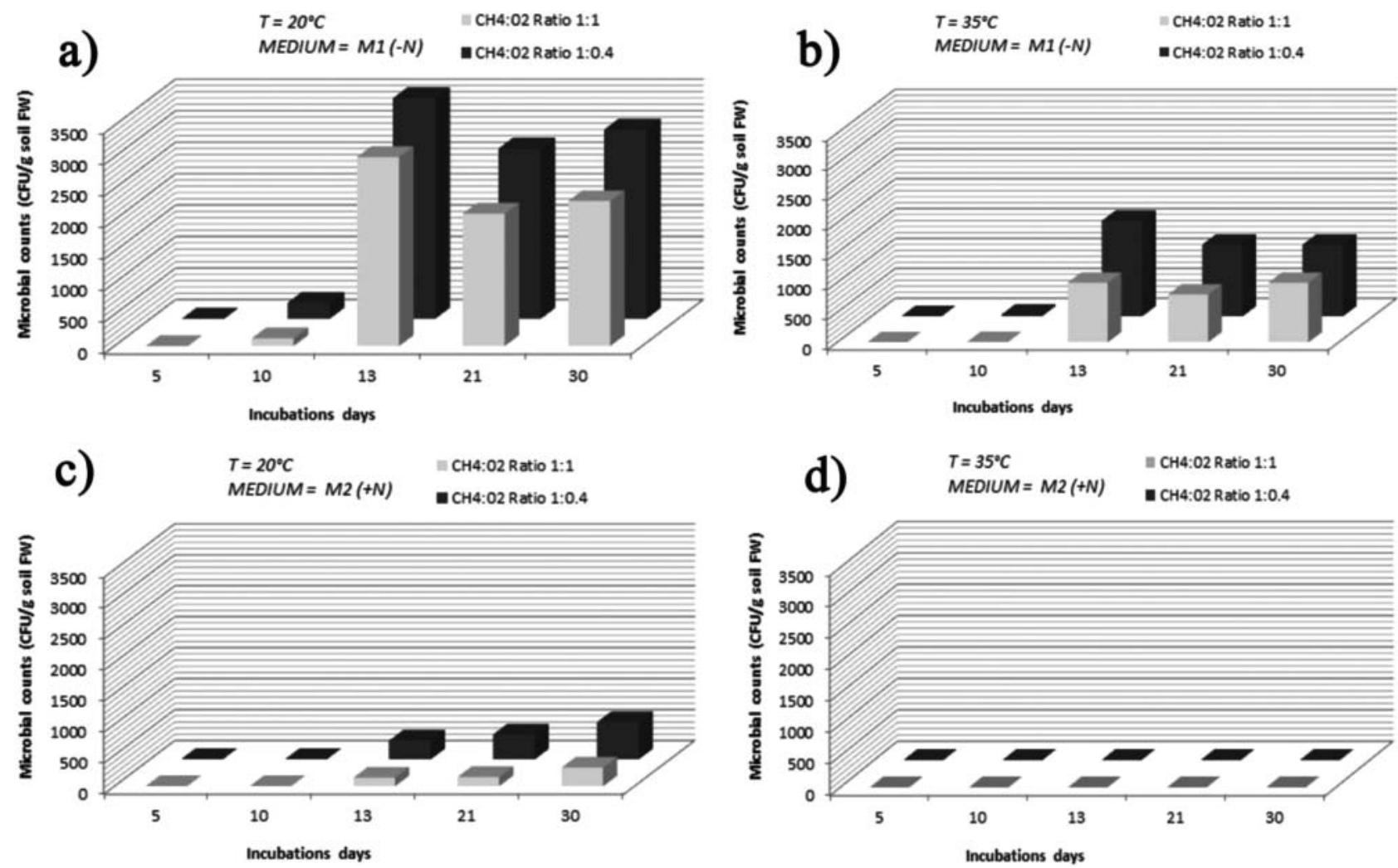

Figure 3. Microbial counts of methanotrophic bacteria at different ratio $\mathrm{CH}_{4}: \mathrm{O}_{2}$. (a) $\mathrm{T}^{\circ}=20^{\circ} \mathrm{C}$ Medium $=\mathrm{M} 1(-\mathrm{N}) ;(\mathrm{b}) \mathrm{T}=35^{\circ} \mathrm{C}$ Medium $=\mathrm{M} 1(-\mathrm{N})$; (c) $\mathrm{T}^{\circ}=20^{\circ} \mathrm{C} \mathrm{Medium}$ $=\mathrm{M} 2(+\mathrm{N}) ;(\mathrm{d}) \mathrm{T}^{\circ}=35^{\circ} \mathrm{C}$ Medium $=\mathrm{M} 2(+\mathrm{N})$. 


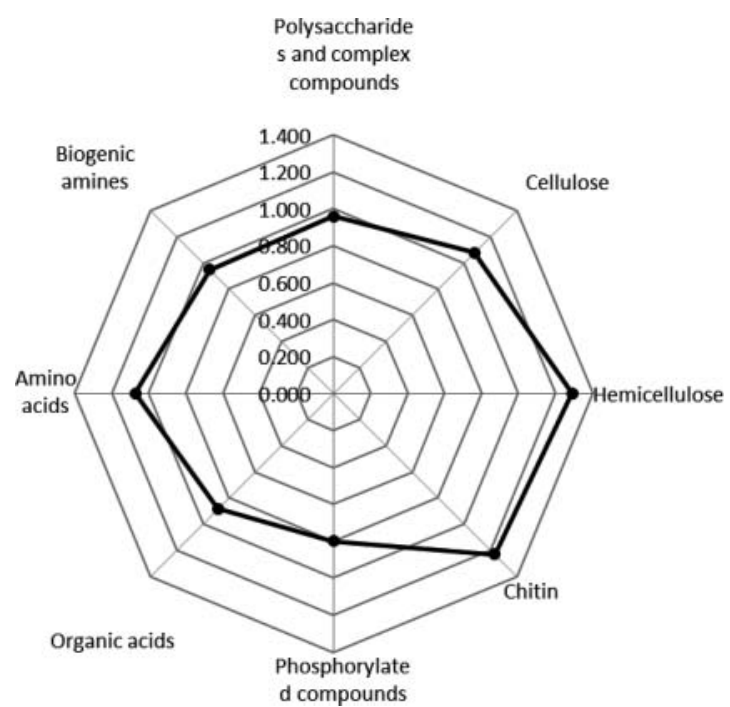

Figure 4. Radar diagrams of bacterial $A W C D$ of all the principal classes of carbon substrates, identified by Biolog ${ }^{\circledR}$ 96-well Eco-Microdishes ${ }^{T M}$, from landfill soil. Values represent means $(n=9)$.

\section{Soil physicochemical parameters and Biolog ${ }^{\circledR}$ analysis}

The average value of $\mathrm{pH}(n=6)$ of the biofilter landfill material resulted to be $7.10 \pm 0.13(\mathrm{SD})$, a value comparable to that considered optimal for the growth of methanotrophs (6.8-7.0). Soil salinity of the same samples $(n=6)$ was $5.24 \pm 0.46(\mathrm{SD}) \mathrm{mS}$ $\mathrm{cm}^{-1}$, which means a non-saline soil and, therefore, suitable for microbial growth. Regarding the analysis of the main nutrients, the soil $(n=6)$ had values of total $\mathrm{N}=2.6 \mathrm{~g} \mathrm{~kg}^{-1}, \mathrm{~K}$ $=165 \mathrm{~g} \mathrm{~kg}^{-1}$, and P-Olsen $=14 \mathrm{~g} \mathrm{~kg}^{-1}$ that can be considered as high, medium and medium-high, respectively. In particular, total $\mathrm{N}$ content is of key importance as it can affect the growth of methanotrophs.

Biolog ${ }^{\circledR}$ assay has been used to assess carbohydrate use and to determine metabolic profiling of microorganisms extracted from different matrixes. ${ }^{[38]}$ The utilization of these specific dishes allows us to determine the microbial catabolic profiles and metabolic diversity indices referring to the number, variety and variability of microorganisms, including diversity within and between groups. ${ }^{[31,32]}$ Among these parameters, total average well color development $(A W C D)$ is particularly important, as it is a measure of the overall metabolic activity of microbial communities. Unfortunately, total $A W C D$ does not necessarily reflect the composition of the bacterial communities as microbial communities can have similar $A W C D$ values but utilize different substrates. In our case, Biolog ${ }^{\circledR}$ absorbance values demonstrated that the $A W C D$ values of all the principal classes of bacterial carbon substrates were $\geq 0.8$ ( $\geq 1.0$ for six of eight classes) (Fig. 4). This can be considered a much equilibrated situation, where all the microbial groups present in the analyzed material exert their catabolic activity on different carbon sources. ${ }^{[39]}$

\section{Conclusions}

The aim of the study was to examine the growth of methanotrophic bacteria, that have a basic role in MAMO systems.
Considering the field-scale biofilter located in Venosa (Basilicata Region, Italy), operative since 2015, samples of biofilter packing material were analysed in laboratory in order to evaluate the environmental factors that most influence the growth of methanotrophic bacteria.

Methanotrophs were plated in selective medium, with and without $\mathrm{N}$ inputs, and incubated at different temperatures in sterile bags filled with air-biogas mixtures. An overall chemical characterization of the packing material and the measurement of metabolic microbial activities (community-level physiological profiles - CLPPs) were carried out by means of chemical methods and Biolog ${ }^{\circledR}$ assay ${ }^{[39]}$, respectively. The results clearly showed that the best temperature range for the growth of methanotrophic bacteria was $20^{\circ} \mathrm{C}$ and that added $\mathrm{N}$ inhibited their growth.

All these factors have to be considered for field-scale biofilters, in order to improve knowledge on some operational issues of MAMO systems and to further examine the development and improvement of currently available industrial installations. The applicative purpose of this study was to provide an original contribution to the LFG treatment challenge.

\section{References}

[1] Stein, V. B.; Hettiaratchi, J. P. A.; Achari, G. Numerical model for biological oxidation and migration of methane in soils. Pract. Periodical Hazard; Toxic; and Radioactive Waste Manage. 2001, 5(4), 225234. doi:10.1061/(ASCE)1090-025X(2001)5:4(225).

[2] IPCC. Climate Change 2014: Synthesis Report. Contribution of Working Groups I; II and III to the Fifth Assessment Report of the Intergovernmental Panel on Climate Change, [Core Writing Team; R. K. Pachauri and Meyer, L. A. (eds.)]. IPCC: Geneva, Switzerland, 2014; pp 151.

[3] Blasing, T. J. Recent greenhouse gas concentrations. 2016 DOI:10.3334/CDIAC/atg.032.

[4] Bogner, J.; Matthews, E. Global methane emissions from landfills: new methodology and annual estimates 1980-1996. Glob. Biogeochem. 2003, Cycles 17, 2, 1065.

[5] Monni, S.; Pipatti, R.; Lehtilä, A.; Savolainen, I.; Syri, S. Global climate change mitigation scenarios for solid waste management. Tech. Res. Cent Finland VTT Publications: Espoo, 2006.

[6] U.S. Environmental Protection Agency. Inventory of U.S Green-house gas emissions and sinks: 1990-2007. 2009, US-EPA, Washington, USA.

[7] Gebert, J.; Gröngröft, A. Performance of a passively vented field-scale biofilter for the microbial oxidation of landfill methane. Waste Manage. 2006, 26, 399-407. DOI:10.1016/j.wasman.2005.11.007.

[8] Amodeo, C.; Masi, S.; Van Hulle, S. W. H.; Caniani, D.; Mancini, I M.; Zirpoli, P. Methane oxidation in a biofilter (part 1): development of a mathematical model for designing and optimization. J. Environ. Sci. Health, Part A, Toxic/Hazard. Substances Environ. Eng. 2015a, 50(13), 1-11.

[9] Amodeo, C.; Masi, S.; Van Hulle, S. W. H.; Caniani, D.; Mancini, I. M.; Zirpoli, P. Methane oxidation in a biofilter (part 2): a lab-scale experiment for model calibration. J. Environ. Sci. Health, Part A Toxic/Hazard. Substances Environ. Eng. 2015b, 50(13), 1-6.

[10] Hettiarachchi, V. C.; Hettiaratchi, J. P.; Mehrotra, A. K.; Kumar, S. Field-scale operation of methane biofiltration systems to mitigate point source methane emissions. Environ. Pollut. 2011, 159, 17151720. DOI:10.1016/j.envpol.2011.02.029.

[11] Hanson, R. S.; Hanson, T. S. Methanotrophic bacteria. Microbiol. Rev. 1996, 60(2), 439-471.

[12] Abichou, T.; Kormi, T.; Yuan, L.; Johnson, T.; Francisco, E. Modeling the effects of vegetation on methane oxidation and emissions 
through soil landfill final covers across different climates. Waste Manage. 2015, 36, 230-40. DOI:10.1016/j.wasman.2014.11.002.

[13] Scheutz, C.; Kjeldsen, P.; Bogner, J. E.; De Visscher, A.; Gebert, J.; Hilger, H. A.; Huber-Humer, M.; Spokas, K. Microbial methane oxidation processes and technologies for mitigation of landfill gas emissions. Waste Manage. Res. 2009, 27(5), 409-455. DOI:10.1177/ 0734242 X09339325.

[14] Chanton, J. P.; Powelson, D. K.; Green, R. B. Methane oxidation in landfill cover soils; is a $10 \%$ default value reasonable? J. Environ. Qual. 2009, 38, 654-63. DOI:10.2134/jeq2008.0221.

[15] Ng, C. W. W.; Feng, S.; Liu, H. W. A fully coupled model for water-gasheat reactive transport with methane oxidation in landfill covers. Sci. Total Environ. 2015, 508, 307-319. DOI:10.1016/j.scitotenv.2014.11.037.

[16] Abichou, T.; Mahieu, K.; Chanton, J.; Romdhane, M.; Mansouri, I. Scaling methane oxidation: from laboratory incubation experiments to landfill cover field conditions. Waste Manage. 2011, 31, 978-86. DOI:10.1016/j.wasman.2010.12.002.

[17] Straka, F.; Crha, J.; Musilova, M.; Kuncarova, M. Biofilters on Old Landfills. In Proc. Sardinia 1999. Seventh International Waste Management and Landfill Symposium 1999, 2, 507-516T. H. Christensen; R. Cossu; R. Stegmann Eds.; Seventh International Waste Management and Landfill Symposium. CISA - Cagliari: Italy.

[18] De Visscher, A.; Schippers, M.; Van Cleemput, O. Short-term kinetic response of enhanced methane oxidation in landfill cover soils to environmental factors. Biol. Fertil. Soils 2001, 33, 231-237. DOI:10.1007/s003740000313.

[19] Du Plessis, C. A.; Strauss, J. M.; Sebapalo, E. M. T.; Riedel, K.-H. J. Empirical model for methane oxidation using a composted pine bark biofilter. Fuel 2003, 82, 1359-1365. DOI:10.1016/S0016-2361(03) 00040-1.

[20] Börjesson, G.; Sundh, I.; Svensson, B. Microbial oxidation of $\mathrm{CH}_{4}$ at different temperatures in landfill cover soils. FEMS Microbiol. Ecol. 2004, 48, 305-312. DOI:10.1016/j.femsec.2004.02.006.

[21] Seongyup, K.; Deshusses, M. A. Determination of mass transfer coefficients for packing materials used in biofilters and biotrickling filters for air pollution control. experimental results. Chem. Eng. Sci. 2008, 63, 841-855. DOI:10.1016/j.ces.2007.10.011.

[22] King, G. M.; Adamsen, A. P. S. Effects of temperature on methane consumption in a forest soil and in a pure cultures of Methanotroph Methylomonas Rubra. Appl. Enviorn. Microb. 1992, 58, 2758-2763.

[23] Boeckx, P.; Van Cleemput, O. Methane oxidation in a neutral landfill cover soil: influence of moisture content; temperature; and nitrogenturnover. J. Environ. Qual. 1996, 25(1), 178-183. DOI:10.2134/ jeq1996.00472425002500010023x.

[24] Einola, J. K. M.; Kettunen, R. H.; Rintala, J. A. Responses of methane oxidation to temperature and water content in cover soil of a boreal landfill. Soil Biol. Biochem. 2007, 39, 1156-1164. DOI:10.1016/j. soilbio.2006.12.022.

[25] Park, S.; Brown, K. W.; Thomas, J. C. The effect of various environmental and design parameters on methane oxidation in a model biofilter. Waste Manage. Res. 2002, 20, 434-444. DOI:10.1177/ 0734242 X0202000507.
[26] Whalen, S. C.; Reeburgh, W. S.; Sandbeck, K. A. Rapid methane oxidation in a landfill cover soil. Applied and environmental microbiology. Appl. Environ. Microbiol. 1990, 56, 3405-3411.

[27] Bender, M.; Conrad, R. Effect of $\mathrm{CH}_{4}$ concentrations and soil conditions on the Induction of $\mathrm{CH} 4$ oxidation activity. Soil Biol. Biochem. 1995, 27, 1517-1527. DOI:10.1016/0038-0717(95)00104-M.

[28] Park, S.; Lee, C. H.; Ryu, C. R.; Sung, K. J. Biofiltration for reducing methane emissions from modern sanitary landfills at the low methane generation stage. Water Air Soil Pollut. 2009, 196, 19-27. DOI:10.1007/s11270-008-9754-4.

[29] Yuan, L.; Abichou, T.; Chanton, J.; Powelson, D. K.; De Visscher, A Long-term numerical simulation of methane transport and oxidation in compost biofilter. Pract. Periodical of Hazard.; Toxic and Radioactive Waste Manag. 2009, 13(3), 96-202.

[30] Page, A. L.; Miller, R. H.; Keeney, D. R. Methods of soil analysis chemical and microbiological properties. Part 2. ed. Agron. Monogr., 2nd ed.; ASA and SSSA: Madison, WI, 1982; Vol. 9.

[31] Pascale, S.; Caivano, M.; Buchicchio, A.; Mancini, I. M.; Bianco, G.; Caniani, D. Validation of an analytical method for simultaneous high-precision measurements of greenhouse gas emissions from wastewater treatment plants using a gas chromatography-barrier discharge detector system. J. Chromatogr. A 2017, 1480, 62-69. DOI:10.1016/j.chroma.2016.11.024.

[32] Zak, J. C.; Willig, M. R.; Moorhead, D. L.; Wildman, H. G. Functional diversity of microbial communities: a quantitative approach. Soil Biol. Biochem. 1994, 26, 1101-1108. DOI:10.1016/0038-0717(94) 90131-7.

[33] Xu, W.; Ge, Z.; Poudel, D. R. Application and optimization of Biolog EcoDishes in functional diversity studies of soil microbial communities. MATEC Web of Conf. 2015, 22, 04015. DOI:10.1051/matecconf/ 20152204015.

[34] Menard, C.; Avalos Ramirez, A.; Nikiema, J.; Heitz, M. Biofiltration of methane: effect of temperature and nutrient solution. WIT Trans. Ecol. Environ. 2009, 127, 239-245.

[35] Madigan, M. T.; Martinko, J. M.; Stahl, D. A.; Clark, D. P. Biology of microrganisms; 14th ed. Pearson Ltd.: Boston, USA, 2015.

[36] Abushammala, M. F. M.; Basri, N. E. A.; Irwan, D.; Younes, M. K. Methane oxidation in landfill cover soil: a review. Asian J. Atmos. Environ. 2014, 8, 1-14. DOI:10.5572/ajae.2014.8.1.001.

[37] Jeong, S.; Nam, A.; Yi, S.-M.; Kim, J. Y. Field assessment of semi aerobic condition and the methane correction factor for the semi-aerobic landfills provided by IPCC guidelines. Waste Manag. 2015, 36, 197-203. DOI:10.1016/j.wasman.2014.10.020.

[38] Sofo, A.; Celano, G.; Ricciuti, P.; Curci, M.; Dichio, B.; Xiloyannis, C.; Crecchio, C. Changes in composition and activity of soil microbial communities in peach and kiwifruit Mediterranean orchards under an innovative management system. Aust. J. Soil Res. 2010, 48(3), 266-273. DOI:10.1071/SR09128.

[39] Sofo, A.; Ciarfaglia, A.; Scopa, A.; Camele, I.; Curci, M.; Crecchio, C.; Xiloyannis, C.; Palese, A. M. Soil microbial diversity and activity in a mediterranean olive orchard using sustainable agricultural practices. Soil Use Manage. 2014, 30(1), 160-167. DOI:10.1111/sum.12097. 